\title{
DOI 10.31392/NPU-nc.series15.2021.9(140).01
} УДК: 796.323 .2

Koryahin V., Doctor of Pedagogical Sciences, Doctor of Physical Education and Sports, Professor, Honored Coach of Ukraine, Head of the Department of Physical Education of the National University "Lviv Polytechnic" Hrebinka H., Senior Lecturer, Department of Physical Education, Lviv Polytechnic National University Borovyk Y.,
Benior Senior Lecturer, Department of Physical Education, Lviv Polytechnic National University Oliyarnyk V.,

Senior Lecturer, Department of Physical Education, Lviv Polytechnic National University Svitlyk V.,

Senior Lecturer, Department of Physical Education, Lviv Polytechnic National University

\section{ACTUAL PROBLEMS OF TRAINING OF HIGHLY QUALIFIED BASKETBALL PLAYERS}

The work presents the study results of the technical and physical preparation level of highly qualified basketball players, as well as the level of development of their aerobic and anaerobic functions, taking into account play functions. According to the study results, the need was found out to increase the efficiency of the high-level players' training system, that, despite positive changes, the training system used in basketball does not fully ensure any sufficient impact upon the energy functions of highly qualified basketball players.

Keywords: physical and technical functional training of highly qualified basketball players.

Коряеін В. М., Гребінка Г. Я., Боровик Ю. І., Оліярник В. І., Світлик В. В. Актуальні проблеми підготовки баскетболістів високого класу. На сучасному етапі система спортивного тренування баскетболістів повинна у повній мірі відображати та враховувати ті дії, що спортсмен виконує в процесі змагань [6]. Сучасний баскетбол потребує від спортсменів високої функціональної підготовки та досконалого володіння усіма технічними прийомами гри. Доведено, що для зростання спортивної майстерності баскетболістів велике значення має фрізична підготовка,та ії органічний взаємозв'язок з технічною підготовкою, який і визначає ефективність тренувального процесу [6-7]. Наукове обгрунтування цього взаємозв'язку дасть змогу ефективно готувати баскетболістів високого класу у процесі багаторічних тренувань.

Дослідження цього питання [ 3, 4, 5] дає змогу стверджувати, що бурхливий розвиток досягнень у світовому спорті потребує безперервного пошуку нових, ефективніших засобів технічної та фрізичної підготовки баскетболістів. Оцінка і аналіз системи підготовки та результатів виступів найсильніших спортсменів світу свідчать, що успіху можливо досягти лише в результаті багаторічних тренувань. Визначено, що саме в юнацькому віці відбувається формування фундаменту для подальшого розвитку $і$ вдосконалення фізичних якостей, від яких в майбутньому залежатиме становлення спортивної майстерності баскетболістів, тому необхідно сприяти усуненню недоліків в рівні фізичного розвитку і фізичної підготовленості юних спортсменів, вже на ранніх етапах багаторічної підготовки [6].

Актуальність дослідження зумовлена потребою в аналізі існуючої системи фрізичної та технічної підготовки юних баскетболістів, що уможливить на науковій основі цілеспрямовано добирати засоби та методи тренування для удосконалення структури комплексної підготовки. Необхідність у визначені основних аспектів фізичної та технічної підготовки юних баскетболістів й визначило вибір теми дослідження.

У роботі представлені результати дослідження рівня технічної і фрізичної підготовленості баскетболістів високої кваліфрікації, а також рівень розвитку їх аеробних та анаеробних функцій з врахуванням ігрових функцій. За результатами дослідження встановлено необхідність підвищення ефективності системи тренування гравців високого зросту, а також те, що системна підготовка, яка використовується в баскетболі, не зважаючи на позитивні зрушення, не забезпечує в певній мірі достатнього впливу на енергетичні фрунції баскетболістів високої кваліфрікації.

Ключові слова: фрізична, технічна підготовленість баскетболістів високої кваліфрікації.

Introduction. At the present stage, the system of sports training of basketball players should fully reflect and take into account the actions that the athlete performs during the competition [6]. Modern basketball requires athletes to have high functional training and perfect mastery of all the techniques of the game. It has been proved that physical training is of great importance for the growth of basketball players' sports skills, and its organic relationship with technical training, which determines the effectiveness of the training process [6-7]. The scientific substantiation of this relationship will allow to effectively preparing high-class basketball players during many years of training.

Research on this issue $[3,4,5]$ suggests that the rapid development of achievements in world sports requires a continuous search for new, more effective means of technical and physical training of basketball players. Assessment and analysis of the training system and results of performances of the strongest athletes in the world show that success can only be achieved as a result of many years of training. It is determined that at young age occurs a formation of the foundation for further development and improvement of physical qualities, which in the future will define the development of sports skills of basketball players, so it is necessary to help eliminate deficiencies of physical development and physical fitness of young athletes [6].

The relevance of the study is due to the need to analyze the existing system of physical and technical training of young basketball players, which will make it possible on a scientific basis to select purposefully the means and methods of training to 
improve the structure of complex training. The need to identify the main aspects of physical and technical training of young basketball players and determined the choice of research topic.

The paper presents the results of the study of the level of technical and physical fitness of highly qualified basketball players, as well as the level of development of their aerobic and anaerobic functions, taking into account the game functions. According to the results of the study, it was established the necessity of increasing the effectiveness of the training system highgrowth players, as well as the fact that the systemic training used in basketball, despite the positive changes, does not provide to some extent sufficient impact on the energy functions of highly qualified basketball players.

Material \& methods. 81 sportsmen took part in the experiment designed determine the level of technical and physical preparedness of the basketball players. All of them were honored masters of sports and masters of sports of the international class.

The examination included 9 special tests [6]. When conducting laboratory examinations cycloergometer, for the purpose of determining the level of aerobic and anaerobic abilities of basketball players, measurements of the size of pulmonary ventilation, the level of oxygen consumption and the allocation of carbon dioxide, and the frequency of cardiac contractions (cardiology) were carried out. 74 honored masters of sports and masters of sports of international class took part in this experiment.

Results and discussion. The study results of the physical preparedness of the highly qualified basketball players are given in Table 1. As it is seen, the running time of the 6-m running in the basketball players performing central functions is $1.30 \pm$ $0.041 \mathrm{~s}$, which is lower than in the forwards $(1.36+0.035 \mathrm{~s})$ and defenders $(1.23 \pm 0.031 \mathrm{~s})$. But it should be borne in mind that the difference is only between the indicators of the centre players and defenders $(P>0,99)$. This indicates that the starting speed of the defenders is better than the starting speed of the central players. If one analyzes the data of the 20 -meter running at 20 , then it turns out that the forwards and the centre players are inferior to the defenders with a high level of reliability difference between the indicators. The maximum speed at the distance in the centre players is lower than that of the forwards and defenders. The increase in speed at the run from 6 to $20 \mathrm{~cm}$ in the centre players is $1.5+0.104 \mathrm{~m} / \mathrm{sec}$, and it is $1.7 \pm 0.124 \mathrm{~m} / \mathrm{sec}$ in defenders. $(P>0.98)$. Thus, we see that tall basketball players, especially those, who perform the functions of central players, are inferior to the defenders both in the initial acceleration and in the possibility of developing the maximum speed at the distance and in the results of 20-meter running. However, it should be noted that in quite a number of indicators that characterize speed qualities of basketball players ( $35 \%$ of the total number), the difference is absent or insufficient. This suggests significant positive changes in the training system of speed qualities in highly qualified basketball players. The high jumping analysis revealed a low level of development of this quality in the highly qualified basketball player. The results of the jump height in the basketball players of different play functions, as evidenced by the results of the studies, are different. The defenders' jump height is $57.7+2.71 \mathrm{~cm}$, which, on average, is by $8.2 \mathrm{~cm}$ higher than in center players and by $5.3 \mathrm{~cm}$ higher than in the forwards $(P>0.999)$ and $(P>0.98)$, respectively.

Table 1

Results of the studies of physical preparedness of highly qualified basketball players

\begin{tabular}{|c|c|c|c|c|}
\hline \multirow[t]{2}{*}{ Indicators } & \multicolumn{3}{|c|}{ Players' functions } & \multirow{2}{*}{$\begin{array}{l}\text { Difference } \\
\text { certainty }\end{array}$} \\
\hline & Centre players $(\mathrm{C})$ & Forwards(F) & Defenders(D) & \\
\hline $\begin{array}{l}\text { 1. 20-metres running- 6- } \\
\text { metres running time (s) }\end{array}$ & $\begin{array}{l}(n=15) \\
1.30 \pm 0.041 \\
0.074\end{array}$ & $\begin{array}{l}(n=17) \\
1.26 \pm 0.035 \\
0.069\end{array}$ & $\begin{array}{l}(n=20) \\
1.23 \pm 0.031 \\
0.066\end{array}$ & $\begin{array}{l}\text { C-F }<0.95 \\
\text { C-D }<0.95 \\
\text { F-D }<0.99\end{array}$ \\
\hline $\begin{array}{l}\text { - 20-metres running } \\
\text { time(s) }\end{array}$ & $\begin{array}{l}3.30 \pm 0.082 \\
0.149\end{array}$ & $\begin{array}{l}3.13 \pm 0.049 \\
0.097\end{array}$ & $\begin{array}{l}3.04 \pm 0.027 \\
0.074\end{array}$ & $\begin{array}{l}\text { C-F }<0.999 \\
C-D<0.999 \\
F-D<0.99\end{array}$ \\
\hline $\begin{array}{l}\text { - maximum speed at a } \\
\text { distance }(\mathrm{m} / \mathrm{s})\end{array}$ & $\begin{array}{l}6.08 \pm 0.016 \\
0.302\end{array}$ & $\begin{array}{l}6.38 \pm 0.021 \\
0.042\end{array}$ & $\begin{array}{l}6.60 \pm 0.031 \\
0.068\end{array}$ & $\begin{array}{l}C-F<0.999 \\
C-D<0.999 \\
F-D<0.99\end{array}$ \\
\hline $\begin{array}{l}\text { - increase in speed from } 6 \\
\text { to } 20 \mathrm{~m}(\mathrm{~m} / \mathrm{s})\end{array}$ & $\begin{array}{l}1.50 \pm 0.104 \\
0.190\end{array}$ & $\begin{array}{l}1.61 \pm 0.100 \\
0.095\end{array}$ & $\begin{array}{l}1.70 \pm 0.124 \\
0.267\end{array}$ & $\begin{array}{l}C-F<0.95 \\
C-D<0.98 \\
F-D<0.95\end{array}$ \\
\hline $\begin{array}{l}\text { Jump height: - height } \\
\text { standing on tiptoes with } \\
\text { the hand above the head } \\
(\mathrm{cm})\end{array}$ & $\begin{array}{l}(n=27) \\
279.6 \pm 2.4 \\
6.1\end{array}$ & $\begin{array}{l}(n=15) \\
271.0 \pm 3.49 \\
6.33\end{array}$ & $\begin{array}{l}(n=27) \\
256.9 \pm 3.42 \\
5.85\end{array}$ & $\begin{array}{l}\text { C-F }<0.999 \\
\text { C-D }<0.999 \\
\text { F-D }<0.999\end{array}$ \\
\hline $\begin{array}{l}\text { - Absolute jump height } \\
(\mathrm{cm})\end{array}$ & $\begin{array}{l}328.1 \pm 3.12 \\
6.1\end{array}$ & $\begin{array}{l}324.1 \pm 3.65 \\
6.38\end{array}$ & $\begin{array}{l}314.4 \pm 3.42 \\
5.85\end{array}$ & $\begin{array}{l}\text { C-F }<0.95 \\
C-D<0.999 \\
F-D<0.98\end{array}$ \\
\hline $\begin{array}{l}\text { 2. Cooper test: Number of } \\
\text { meters for } 12 \text { minutes of } \\
\text { running }\end{array}$ & $\begin{array}{l}(\mathrm{n}=17) \\
2845.3 \pm 91.4 \\
178.9\end{array}$ & $\begin{array}{l}(n=20) \\
3075.5 \pm 53.5 \\
114.6\end{array}$ & $\begin{array}{l}(\mathrm{n}=21) \\
3087.9 \pm 71.5 \\
157.5\end{array}$ & $\begin{array}{l}\text { C-F }<0.999 \\
C-D<0.999 \\
\text { F-D }<0.95\end{array}$ \\
\hline $\begin{array}{l}\text { 3. } 3 \times 40 \text { s running after } 1 \\
\text { min. rest: number of } \\
\text { meters for } 120 \mathrm{~s} \text { of } \\
\text { running }\end{array}$ & $\begin{array}{l}(n=12) \\
560.9 \pm 10.04 \\
15.95\end{array}$ & $\begin{array}{l}(n=15) \\
581.2 \pm 6.52 \\
13.55\end{array}$ & $\begin{array}{l}(n=21) \\
548.8 \pm 10.92 \\
24.08\end{array}$ & $\begin{array}{l}\text { C-F }<0.99 \\
C-D<0.99 \\
\text { F-D }<0.95\end{array}$ \\
\hline
\end{tabular}

The correlation analysis, carried out by us, between the height data and the jump height indicators in highly qualified basketball players showed that there is a rather high but negative dependence $(P=-0.589)$. The studies have shown that in terms of 
the development of general and special high-speed endurance in basketball players of high qualification, there are significant reserves, especially in the centre players. The average factor in the Cooper test in the centre players is $2845.3 \pm 91.98$ meters; it makes up $3075.5 \pm 53.55$ meters in the forwards, and it is $3087.9 \pm 71.48$ meters in defenders $(P>0.900$ among all the indicators). The difference between the average indicators of the centre players and defenders significant and makes up $242.6 \mathrm{~m}$, whereas between the centre players and the forwards it is $239.2 \mathrm{~m}$. It should be noted that the height of the forwards, as well as of the central players is above $200 \mathrm{~cm}$. The indicators of special high-speed endurance show the same results. During the test, the average indicator in the $3 \times 40 \mathrm{~m}$ running is $569.9 \pm 10.04 \mathrm{~m}$ in the centre players, $581.2 \pm 6.52 \mathrm{~m}$ in the forwards and $548.8 \pm 10.92 \mathrm{~m}$ in the defenders. The difference between the indicators of the centre players and the forwards is $20.3(P>0.99)$; it is $23.9 \mathrm{~m}(P>0.99)$ between the centre players and defenders and $3.5 \mathrm{~m}(P>0.95)$ between the forwards and defenders.

The analysis of the study results of the highly qualified basketball players' technical preparation has shown that the advantage of the defenders over the centre players and forwards is observed all indicators, with the exception of two: the work time in the basketball shooting test and overall work ability in shots. This suggests that the level of technical preparation of tall players has significant reserves, especially in passing the basketball using one hand from the shoulder, which is performed using the "weaker" hand (usually the left hand), and in foul shot. It is known that during the match, tall players, and especially centre players, most often perform foul shots. But they have a lower scoring rate of $25.15 \pm 0.875(83.8 \%)$, while a scoring rate of defenders is $26.5 \pm 0.689$ (88.3\%). The reliability of the difference between the indicators is high - $P>1.98$.

A significant contribution to the problem of assessing the level of physical preparation may be the study of the functional capabilities of basketball players [1-4].

As it is known, one of the most important indicators of physical work capacity, which characterizes the level of development of aerobic functions, is the maximum oxygen consumption. In basketball players of high qualification, this indicator reaches the value of $58.5 \pm 5.59 \mathrm{ml} / \mathrm{kg} / \mathrm{min}$. These values of the maximum $\mathrm{O}_{2}$ consumption are lower than the similar indicators of representatives of other types of sports.

It should be noted that in the representatives of cyclic sports, the maximum oxygen consumption reaches $70 \mathrm{ml} / \mathrm{kg}$ and above [2]. Relatively small values are recorded in other indicators that characterize the level of development of aerobic and anaerobic performance of sportsmen. Average indicators of critical power in highly qualified basketball players made up $1741 \mathrm{~kg} / \mathrm{m}$ min., PANO-60.7\%, PWS $170-1325 \mathrm{~kg} / \mathrm{m}$ min; the total "excess" of $\mathrm{ICO}_{2}$ emission is 4.861.

The analysis of the functional capability indicators of highly qualified basketball players, taking into account their game functions, showed that the reliable difference between them is observed in $25.9 \%$ of cases. The difference between the indicators of the central players and forwards is significant in $16.6 \%$ of cases, between centre players and defenders - in $55.5 \%$ of cases and between forwards and defenders $-5.5 \%$ of cases.

Conclusions. 1. The studies have revealed that in $20.2 \%$ of cases, there is no difference between physical preparedness indicators or the difference is uncertain in players with different functions. In the technical preparedness indicators, this percentage is 30.5. This shows, on the one hand, the certain progress in the system of training of highly qualified basketball players, and on the second hand, this shows the necessity to increase the efficiency of the training system of tall players, especially of the players performing functions of "center players". 2. The determination of the maximum of aerobic and anaerobic performance indicates that, despite positive changes, the system of preparation used in basketball, influence upon the energy functions that form the basis of both general and special endurance. This is evidenced by the data obtained from basketball players of various game functions, but it does not fully ensure sufficient.

Conflicts of interest - The authors declare no conflict of interest.

\section{Sources and literature}

1. Asmussen, E.,\& Nielson, M. (1955). Cardiac output during muscular work and its regulation. Physiol.Rev, 1, 778.

2. Volkov N. I. (1990). Bioenergetics of human intense muscular activity and ways to improve the performance of sportsmen: Dissertation by the Doctor of Biological Sciences. Moscow (in Russian).

3. Gomelsky, A. Ya., Lunichkin, VG, \& Rodionov, A. V. (1986). Different approach. Kind of Sports, No 2, 13-14 (in Russian).

4. Denisenko, A. (2017). Development of applicative coordination abilities of $12-13$ years old pupils through basketball elements, Journal of Physical Education and sport, 17(2), 79, 527-532.

5. Keller, V.S., Platonov, V.M. (1993). Teoretyko-metodychni osnovy pidgotovky sportsmeniv[Theoretical-methodic basis of sportsmen training]. Lviv,

6. Kondrashin, V., Koryahin, V. (1978). Training of the basketball players of high grade. Kiev, publishing house "Zolorov'ya,

P. 93.

7. Koryahin, V. (1994). The structure and content of modern training of basketball players: Dissertation by the Doctor of Biological Sciences. Moscow (in Russian). Ukrayinska Sportyvna Asotsiatsiya, 480.

8. Koryahin, V.M. (1998). Training of the highly skilled basketball players. Textbook for the correct physical education. Lviv, publishing house "Krai", 192. 9. Krutsevych T.Y., Vorobyov M.I., Bezverkhnya G.V. Control in physical education of children, adolescents and youth: textbook. Kyiv: Olympic literature, 2011. $224 \mathrm{p.}$.

10. Malikov M.V., Svatev A.V., Bogdanovska N.V. Functional diagnostics in physical education and sports: textbook. Zaporizhzhia: ZDU, 2006. 227 p.

11. Poplavskyi L. Yu. (2004). Basketball. Kyiv: Olimpiiska Literatura,447.(in Ukrainian).

12. Romanenko V. A. Diagnostics of motor abilities: textbook. Donetsk, 2005. 290 p.

13. Stolyarov V.I. Theory and methodology of modern physical education: the state of development and the author's concept: monograph. Kiev: Olympic Literature, 2015. 704 p. 